I do not believe that any geologist will ever be able to trace a boundary in those slates and grits, so as to subdivide them into two clearly marked groups, such as Infracombe, Combe Martin, Marwood, Pilton beds, etc., until that is done by a good stratigraphical geologist, independently of all fossil evidence. That fossil evidence is not worth a rush in this case, because we are merely reasoning in a circle, drawing a boundary to suit the fossil localities, and then using the fossils to prove the correctness of the boundary. According to the results of my field work, (hasty and imperfect enough, doubtless in Devon, but still based upon the experience acquired by thorough and exhaustive work, carried on patiently for years in Ireland), the Old Red Sandstone of Porlock, Minehead and Dunster is brought up again by a great fault in the centre of North Devon, and forms a ridge, running from Morte Bay to Wiveliscombe, the Lynton, Combe Martin and Ilfracombe beds being part of the Marwood and Barnstaple beds.

If I am mistaken in this, then the central red ridge from Morte Bay to Wiveliscombe is different from anything we have in Ireland, and can be used to divide the grey slates of North Devon into an Upper and Lower group, still having the genuine Old Red Sandstone of Porlock, Minehead, and Dunster below them all, and the Coalmeasures conformably above them all.

These Devonian rocks will then rest, like their contemporaries, the Carboniferous Slate in Ireland, between the top of the Old Red and the base of the Coal-measures, and will be the muddy and sandy representatives of the Carboniferous Limestone, with a somewhat different fauna, arising partly from difference of habitat and partly from difference of province. The contemporaneity of different assemblages of fossils in closely adjacent areas, which is the explanation of Barrande's Colonies, has not yet been sufficiently worked out or attended to. It has been the cause, not only of the Devonian delusion, as I have called it above, but of the confusion among the Cambro-Silurian series of Wales and elsewhere.

I, for one, cannot feel any confidence in the stratigraphical groups of these rocks, established merely to suit the supposed horizons of certain fossils, and not worked out by honest stratigraphical obserrations in the field.

Lastly, let me say that I seem to myself to have been endeavouring to fix the exact place of the so-called Deronian system instead of explaining it away. Yours,

Dublns, Jantuary 6th, 1867.

J. Berte Jukhs.

\title{
FORM OF THE GROUND AND FAULTS IN THE DRIFT.
} To the Editor of the Grocogican Magazing.

SrR,-Allow me to correct a slight error which has crept into print, although not in the proof of my paper, in your January No. At page 9, line 5, for "became " read become, and for "sloping," in line 10 , read slope, when it will be seen that (however ill oxpressed) 
I refer to the old shape of the ground and not to the angles of the overlying deposits. At foot of page 10, for "Benluben" read Benbulben.-While writing I may mention, in connection with the subject of faults in drift, a suggestion, made with reference to those illustrated in Plate II. Fig. 8 of the above number and others, in Explanation Sh. 126, Mem. Geol. Survey, Ireland, to the effect that they might have boen caused in tenaceous drift by the intersection of planes of separation inclined towards each other so as to meet along a line also inclined to the horizon: and enclosing wedge-shaped masses of the material which from passage of water or from being deprived of support at their larger ends by natural causes would slide into lower positions; subsequent denudation settlement, etc., exposing faulted sections and perhaps obliterating other marks of subsidence.

None of these drift faults or dislocations were found to penetrate the underlying (limestone) rock, but I have heard of one from my friend, Mr. Kinahan, which is said to fault both the Coal-measures and superficial deposits in the Castle Corner Field.-Wishing your Magazine the compliments of the season, I am truly yours,

London, January $18 t, 1867$.

A. B. Wrnne.

\section{DENODATION AND THE FORM OF THE GROUND.}

To the Editor of the GroLogidal M.agazine.

Srr,-My old colleague, Mr. A. B. Wynne, appears to have quite forgotten the S.W. of Cork and Kerry, when he says in the Grological Magazine, for January, 1867, p. 6, "Isolated rocky pillars upon hills, the very aspects of which suggest that the stone is being gradually disintegrated by rains." Does he forget the Skellings off the coast of Kerry; the Fasnet Rock (See Woodcut)

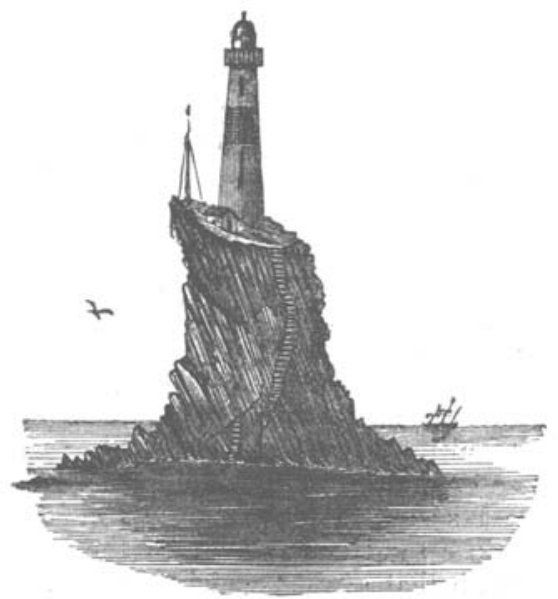

DABNEF Rock AND LJeBt-HovBr, coast of Cork, with soundings of 40 fathoms, 6 fathoms from the rock 